\title{
Conversion of tidal channel water to shallow As-rich groundwater through reduction of ferric oxides in the tidal deltaplain of SW Bangladesh
}

\author{
JOHN C. AYERS ${ }^{1 *}$, CHELSEA PETERS ${ }^{2}$
}

${ }^{1}$ Dept. of Earth \& Env. Sciences, Vanderbilt University (* correspondece: john.c.ayers@vanderbilt.edu)

${ }^{2}$ Dept. of Earth Sciences, Univ. of Delaware (cnpeters@udel.edu)

Groundwaters in the shallow aquifer of the tidal deltaplain in Southwest Bangladesh are $\mathrm{Na}-\mathrm{Cl}$ type and predominantly sulfate-reducing, with average conductivity $\mathrm{SpC}=8 \mathrm{mS} / \mathrm{cm}$, $\mathrm{pH}=7.1, \mathrm{Eh}=13 \mathrm{mV}, \mathrm{As}=40 \mathrm{ug} / \mathrm{L}, \mathrm{S}=5 \mathrm{mg} / \mathrm{L}$, and high dissolved organic carbon of 11-57 mg/L [1]. Most groundwater samples from tubewells have As concentrations above the WHO drinking water guideline of $10 \mathrm{ug} / \mathrm{L}$. This is usually attributed to reductive dissolution of hydrous ferric oxides such as goethite and mobilization of adsorbed As. We tested the hypothesis that these As-rich groundwaters formed by burial of Na-Cl type tidal channel water and progressive reduction by organic matter using a reaction path model in the Geochemists Workbench v. 14. Average groundwater salinity indicates an initial solution containing $20 \%$ saline dry season tidal channel water and $80 \%$ rainwater. This mixture has $\mathrm{SpC}=8 \mathrm{mS} / \mathrm{cm}$, $\mathrm{pH}=7.4, \mathrm{Eh}=780 \mathrm{mV}, \mathrm{As}=0.14 \mathrm{ug} / \mathrm{L}$, and $\mathrm{S}=127 \mathrm{mg} / \mathrm{L}$. In the model $1 \mathrm{~kg}$ of solution is titrated with 4.5 mmoles of the reducing agent acetic acid in the presence of 10 mmoles of goethite. Adsorption onto goethite is described using the double layer surface complexation model. Progressive reduction consumes goethite, precipitates magnetite, and releases arsenic to solution. Next, sulfate is reduced to sulfide, which combines with dissolved ferrous iron to form pyrite. Dolomite precipitates early, followed by siderite at $\sim 3$ mmoles of reactant. Pyrolusite $\left(\mathrm{MnO}_{2}\right)$ precipitates and then dissolves. An inverse mass balance model in Phreeqc yields results similar to the forward model: progressive reduction causes dissolution of goethite and then precipitation of magnetite and then pyrite. The final solution has $\mathrm{SpC}=8 \mathrm{mS} / \mathrm{cm}, \mathrm{pH}=7.9$, $\mathrm{Eh}=-314 \mathrm{mV}$, As $=51 \mathrm{ug} / \mathrm{L}$, and $\mathrm{S}=0.0004 \mathrm{mg} / \mathrm{L}$. Groundwater compositions mostly agree with model results, indicating that groundwaters are essentially connate waters, with variable but small amounts of dilution by recharge.

[1] Ayers et al. (2016) Geochem. Trans. 17:4, doi: 10.1186/s12932-016-0036-6 